Pregledni znanstveni članek Review scientific paper (1.02) Besedilo prejeto Received: 2. 10. 2020; Sprejeto Accepted: 11. 10. 2020

UDK UDC: 159.942:929Stein E.

DOI: 10.34291/Edinost/75/02/Simonic

(C) 2020 Simonič CC BY 4.0

\title{
Barbara Simonič
}

\section{Dialoške razsežnosti empatije pri Edith Stein}

\author{
Dialogic Dimensions of Empathy at Edith Stein
}

Izvleček: Empatija je pomemben mehanizem medosebne komunikacije in dialoga. Označuje sposobnost vživeti se v čustva in tudi misli drugih in tako imeti vpogled v doživljanje nekoga drugega. Empatija nam omogoča, da se postavimo v situacijo sočloveka, kar je temeljno bistvo dialoškosti - biti človek s človekom. Ta sposobnost razumevanja drugih je že od nekdaj zanimala številne mislece. Med njimi je bila tudi Edith Stein (1891-1942), ki se uvršča med pomembne ženske, ki so zaznamovale 20. stoletje. Bila je prepoznavna filozofinja in učiteljica, rojena kot Judinja, kasneje pa kristjanka in mučenka ter prva oseba judovskega rodu od časa dni prve Cerkve, ki je bila kanonizirana. Empatiji je Edith Stein posvetila svojo doktorsko disertacijo z naslovom O problemu empatije, hkrati pa je tudi s svojim kasnejšim raziskovanjem in načinom življenja razkrivala, kaj pomeni biti empatičen in kako živeti dialoškost s sočlovekom in Bogom. V prispevku predstavljamo temeljne vidike razumevanja empatije pri Edith Stein in izpostavljamo pomen empatije kot kompetence, ki je ključnega pomena za resnične, globoke in zdrave medosebne odnose in dialog.

Ključne besede: empatija, Edith Stein, vzajemnost, intersubjektivnost, fenomenologija, oseba

\begin{abstract}
Empathy is an important mechanism of interpersonal communication and dialogue. It could be defined as our ability to feel another person's feelings and thoughts, and thus gain insight into someone else's experience. By this we put ourselves in the situation of other, which is the fundamental essence of dialogue - to be human with other human. The ability to understand others has always interested many authors. Among them was Edith Stein (1891-1942), one of the important women who marked the $20^{\text {th }}$ century. She was a recognizable philosopher and teacher, born a Jew, and later a Christian and a martyr, and the first Jew born person since the days of the first Church to be canonized. Edith Stein dedicated her doctoral dissertation to empathy, entitled On the Problem of Empathy, and through her later research and way of life revealed what it means to be empathetic and how to live a dialogue with another human being and God. In this paper, we present the fundamental aspects of understanding empathy at Edith Stein and highlight the importance of empathy as a competence that is crucial for real, deep and healthy interpersonal relationships and dialogue.
\end{abstract}

Key Words: empathy, Edith Stein, mutuality, intersubjectivity, phenomenology, person 


\section{Uvod}

Empatija je kompetenca, o kateri ne moremo razmišljati zunaj konteksta medosebnih odnosov in medsebojne povezanosti, kar je v današnjem, velikokrat razosebljenem svetu lahko težavno. Na drugi strani pa ravno ta kompetenca nosi v sebi velik potencial, saj lahko v času, ko je družba podvržena procesom globalizacije in spreminjanju vzorcev in doslej veljavnih norm sobivanja, ravno sposobnost empatije ponovno prebudi občutek povezanosti z drugimi, to pa v prihodnosti lahko pomeni tudi večjo možnost za preživetje. (O’Hara 1997, 295-296) Empatija tako postaja in ostaja pomembna ne le v intimnih odnosih, temveč tudi na globalni ravni našega sobivanja (Rifkin 2009, 2-3). V prispevku bomo opisali temeljne značilnosti empatije, pri čemer se bomo podrobneje naslonili na razumevanje empatije pri Edith Stein, nakazali pa bomo tudi nekatere vidike v dialoškosti človeka, ki se ob prisotnosti empatije lahko oplemenitijo in poglobijo.

\section{Empatija}

Sodobni avtorji empatijo opredeljujejo kot sposobnost posameznika, da se postavi na mesto drugega, pri čemer zazna in razume oz. se vživi v občutja in misli druge osebe, vendar se z njo ne poistoveti na način, da bi izgubil svoj lastni jaz (Baron-Cohen 2003, 21-22; Guttman 2000, 345; Lachmann 2008, 9; van der Mark 2001, 2). Empatija je zavedanje in deljenje čustev ter misli z drugo osebo. To omogoča posamezniku, da se postavi v psihološki okvir doživljanja druge osebe in zaznava stanje tako, kakor ga doživlja druga oseba. V naravi empatije tako izstopata dve komponenti oz. vidika, ki sta med seboj prepletena in povezana: spoznavni (kognitivni), ki je osnovan na razumskem in intelektualnem razumevanju izkušnje druge osebe, in afektivni (čustveni), ki v ospredje postavlja enakost čustvenega doživljanja obeh udeležencev. (Duan in Hill 1996, 263) Sodobno pojmovanje empatije torej združuje afektivno in spoznavno komponento empatije, kjer je pomembno tako spoznavno zavzemanje gledišča drugega kot afektivna sposobnost doživljanja celega spektra čustev (Tangeny in Dearing 2002, 79-81). 
V okviru teh opredelitev poteka tudi znanstveno raziskovanje empatije. Ker je empatija tako pomembna in univerzalna, so se in se še z njenim raziskovanjem (neposredno ali posredno) ukvarjajo različne znanosti. Teoretične in empirične znanstvene razprave se v glavnem vrtijo okoli iskanja jasne celostne opredelitve pojma empatija, pri čemer vedno poudarjajo tudi pomembnost empatije v sodobni realnosti življenja. O pomenu občutenja in razumevanju drugega so govorili že antični (npr. Aristotel) in krščanski filozofi (npr. Avguštin, Laktancij, Tomaž Akvinski), kasneje škotski moralni filozofi (npr. Hume, Smith) (Škof 2002, 71-119), estetiki (npr. Vischer, Lipps) ter fenomenologi (npr. Husserl, Steinova) (Gallese 2003, 175-176). Filozofija in psihologija sta si glede pojmovanja empatije sorodni, saj s pojmom empatija označujeta stanje, ki pomeni zavedanje in razumevanje notranjega stanja drugega.

Na področju filozofije se je študij empatije pojavljal predvsem v kontekstu prizadevanja razjasniti pojem subjekta (osebka), pri čemer se je odprlo vprašanje intersubjektivnosti, v tem okviru pa tudi empatije (Hribar Sorčan 2008, 13). O tem je največ razprav prisotnih v okviru fenomenologije, ki se je trudila podrobno opisati bistvo pojava vživljanja. Edmund Husserl, njegova učenka Edith Stein in drugi so pojem uporabili in razvijali za pojasnjevanje intersubjektivnosti med mislečimi posamezniki. V tem okolju intersubjektivnosti empatija ne samo dovoljuje posamezniku prepoznati misli drugih in druge kot misleča bitja, ampak pomaga tudi pri razvoju reflektivnega in samokritičnega pogleda nase, s tem ko omogoča prepoznati, kakšno mnenje imajo drugi o meni (Stueber 2006, 9). Empatija je izkustvo, v katerem občutimo, da naša dejanja prebijajo naš lastni svet in da so drugi del našega lastnega sveta. V tem je po Husserlovem pojmovanju skrito spoznanje, da drugi človek ni že povsem izgotovljen in zgrajen osebek, ki mu pripisujem duševna stanja, pač pa je drugi zame drugi zato, ker ima zame neko bivanjsko vrednost, saj sotvori svet, v katerem živim. (Hribar Sorčan 2008, 20)

\section{Razumevanje empatije pri Edith Stein}

Edith Stein (1891-1942), Husserlova učenka, se je še dodatno poglobila v raziskovanje empatije, najprej v svoji doktorski disertaciji leta 1917 O problemu empatije (nem. Zum Problem der Einfühlung), nato pa se 
je (posredno) dotika tudi v svojih kasnejših delih. Empatijo opredeli kot našo izkušnjo doživljanja drugega (Stein 1989, 1). Empatija je pojav, pri katerem ena oseba dojema drugo osebo. Empatične izkušnje so tiste, pri katerih doživljamo določeno vsebino ali dogodek, vendar vedno kot nekaj, kar se ne dogaja nam, ampak je to izkušnja drugega. Tako kot spomin ali domišljija spada tudi empatija med deje predstavljanja. Pri tem je vsebina prisotna v predstavi, ne pa dejansko. Pri empatiji gre za predstave tega, kar drugi izkuša oz. doživlja. Ko pa si oseba predstavlja to izkušnjo, je »potegnjena « v izkušnjo druge osebe in s tem sposobna videti položaj z njenega gledišča. Prebudijo se podobna občutja kot pri drugem, le da se tisti, ki je empatičen, v resnici ne nahaja v istem položaju. (Nilsson 2003, 73-78) Pri empatiji doživljamo isto vsebino, kot jo ob nekem dejanskem dogodku doživlja drugi, pri čemer se nam zdi, kakor da se dogodek dogaja nam. To nam omogoča dostopati do notranjega doživljanja drugega na način, ki ni odvisen od naše sposobnosti dobrega ugibanja. (Borden 2003, 27-29)

V nadaljevanju v sintetizirani obliki podajamo nekaj temeljnih vidikov razumevanja empatije, kakor izhaja iz različnih virov in razprav Edith Stein. ${ }^{1}$ Čeprav je v O problemu empatije in v kasnejših delih (npr. Končna in večna bit, Znanost križa) Steinova naslavljala širša filozofska (npr. zgradba psihofizičnega posameznika, možnost in dej, vprašanje biti, struktura osebe) in duhovna vprašanja (npr. molitev, trpljenje, temna noč duše), je vseeno mogoče izpostaviti nekatere vidnejše poudarke, ki so pomembni pri razumevanju empatije kot take. Njen sklep je, da ima empatija edinstveno naravo, da je sui generis. V disertaciji podaja natančen opis različnih vidikov empatije v okviru fenomenološke metode, temeljne postavke pa s kasnejšimi deli in tudi življenjskimi izkušnjami, zlasti z izkušnjo žive vere in življenjem iz nje, še poglobi.

\subsection{Opredelitev empatije in narava empatije}

Steinova poudarja, da je v razpravi o empatiji ne zanima način empatije, ampak »kaj«je empatija, torej dojetje bistva empatije. Empatijo opredeli kot naše izkustvo doživljanja drugih. Gre torej za dejanje, v katerem je mogoče

1 Sinteza je rezultat raziskovanja v okviru doktorske disertacije Empatija kot temeljni antropološki odnos: Od izročila preko Edith Stein do relacijske teorije (Simonič 2010). 
izkusiti in tako usvojiti, razumeti tuje doživljanje. Empatija je dojemanje drugih osebkov in njihovih doživljajev. To doživljanje ni rezultat razumskega ali namernega miselnega procesa, ampak so nam tuji osebki in njihovi doživljaji dani. Empatija je torej dana. Gre za dejanje, ki smo mu podvrženi, pri tem ko čutimo enost z drugimi, pa ne izgubimo lastne identitete. Namesto tega doživljamo drugo osebo kot čuteče živo telo, ki pripada jazu, ki je, tako kot smo to tudi mi, središče orientacije v svetu. Našemu jazu je dana izkušnja drugega jaza in njegovega sveta. V tej empatični izkušnji osebe so in ostajajo ločene in edinstvene. O empatiji je tako mogoče reči, da ne gre samo za to, da mi vstopamo v drugega, ampak da drugi vstopajo in vdirajo v nas in v našo zavest, saj empatija v bistvu ni dejanje, ki bi ga mi hoteli, ni dejanje naše volje, ampak se zdi, da se nam kar zgodi (je spontana): mi smo pasivni, empatične izkušnje pa so nam dane. Seveda je to pogojeno z določeno stopnjo odprtosti in sprejemanja drugih. Na določen način smo recipročno drug za drugega ranljivi, meje so v določenem smislu prekoračene, vendar pa je naš občutek celovitosti in integritete pri tem ohranjen. (Simonič 2010, 106)

\subsection{Vsebina empatije}

Z empatijo doživljamo enako vsebino, kakor jo doživlja drugi, in tako imamo dostop do notranjega življenja drugih, pri čemer dojemanje tega notranjega življenja drugih ni odvisno od naše sposobnosti dobrega ugibanja. Empatija je izkušnja tuje notranjosti in kot taka ni izvirna, govori pa o neki izvirni izkušnji (izvirna je za drugega). Pri empatiji gre za doživljaj, ki ga trenutno doživljam, ki se odvija v tem trenutku, vendar pa je vsebina tista, ki v tem trenutku ni moja, ampak je od drugega. Izkušnja sama je tako izvirna, dejansko nekaj doživljam, vendar pa to, kar doživljam, kar je vsebina tega doživljanja, ni izvirno moje. Trenutna izkušnja nam tako govori o izkušnji drugega. Lahko npr. čutimo, da je naš bližnji žalosten, vendar pa ta žalost ni naša. Empatija je dvostranska izkušnja: je naša, hkrati pa govori o nečem, kar ni naše nikoli bilo. V empatičnih izkušnjah doživljamo nekaj, neko vsebino ali dogodek, ki ga podoživimo, vendar pa to ni nekaj, kar bi se v tem trenutku dogajalo nam, ampak se to dogaja drugemu. Z empatijo izvirno doživljamo to, česar ne bomo nikoli izvirno doživljali. (Simonič 2010, 106-107) 


\subsection{Empatija je proces}

Steinova ugotavlja, da se empatične izkušnje se odvijajo na treh stopnjah: 1. pojav doživljaja; 2. razvoj doživljanja; 3. konkretiziranje in opredmetenje ekspliciranega doživljaja. Če poskusimo ta tristopenjski proces opisati s primerom, na prvi stopnji empatičnega doživljanja zaznam, da drugi nekaj doživlja. Doživljanje drugega se predme postavi kot dejstvo. Dejstvo je npr., da je drugi vesel, in to njegovo veselje je zame zunanje dejstvo. Ko pa poskušam jasneje razumeti doživljanje drugega, nekako podoživim to zunanje dejstvo, sem potegnjen v ta doživljaj in izkušam, kaj pomeni imeti ta doživljaj. Na tretji stopnji pa pride do umika od tega doživljanja: razumem, da imam pred seboj še vedno doživljaj drugega, vendar pa je razumevanje tega tujega doživljaja bogatejše, ker sem sam notranje izkusil, kaj pomeni imeti tak doživljaj. Med temi tremi stopnjami empatije je bistvena druga stopnja, ko smo potegnjeni v doživljaj druge osebe in tako vidimo to stanje z njenega zornega kota, kar je bistveno drugače, kot če bi ostali samo na ravni dejstev, kjer bi lahko samo rekli, da smo opazili, da je drugi npr. vesel, dlje pa se ne bi spuščali. Ta potegnjenost v doživljanje obogati razumevanje celote doživljanja. (Simonič 2010, 107-108)

\subsection{Empatija je gradnik človeške osebe in pot do samospoznanja}

Empatični deji vodijo tudi k zavedanju in integraciji občutka za človeško osebo. To se zgodi na več načinov. Najprej gre za to, da empatični deji omogočajo pridobiti razumevanje tuje osebe in njenih vrednot. Drugega pri tem dojemamo kot kompleksno bitje, kakršno smo mi sami. Drugi je prav tako čuteče živo telo, ki pripada jazu, kakor moje čuteče živo telo pripada mojemu jazu. Druge je tako mogoče prepoznati kot osebe. Dalje je treba poudariti, da preko empatičnih izkušenj drugih prihajamo tudi do podobe in vrednosti svoje lastne osebe. Ko reflektiramo lastno empatično doživljanje drugih, si osvetlimo lastne sposobnosti, vrednote, primanjkljaje in si obogatimo ter oblikujemo lastno podobo sveta. V tem primeru nase gledamo kot na predmet, stopimo iz sebe in gledamo nase kot na drugega, vse to pa nam omogoča, da ocenimo in se odločimo, kakšni bi radi postali in kako moramo ravnati, da to dosežemo. Za to oceno pa potrebujemo kriterij, ki je v tem primeru druga oseba, ki jo empatično izkušamo. Z empatijo prihajamo tako tudi do spoznanja, v čem se razlikujemo od drugih. To samospoznanje omogoča samovrednotenje. Človek 
tako samega sebe ne more $\mathrm{v}$ polnosti razumeti niti se poznati brez odnosa z drugimi. Ko tako zaznavamo druge, njihove potenciale in doživljanje, nas to informira o tem, kje smo mi in kaj vse še lahko postanemo. Veliko možnosti nam je namreč prikritih, ko pa vidimo druge, lahko prepoznamo svoje neuresničene potenciale. Ker smo ljudje nenehno v razvijanju in ker je naše znanje o samih sebi in lastnih potencialih nepopolno, so potrebni drugi ljudje, da se zavemo, kdo smo in kam še lahko gremo. Drugi pa so kot gradniki naše osebnosti pomembni še zaradi enega vidika, v katerem lahko govorimo o zametkih vzajemnosti. Steinova to razsežnost opiše kot nenehno ponavljanje empatije, pri čemer ima v mislih sposobnost z empatijo dojeti, da so drugi empatični do nas. Razumemo, da drugi razumejo naše doživljanje, pri tem pa dojemamo tudi to, kako nas drugi razumejo, kaj mislijo o nas in o naših dejanjih. Ko se z empatijo zavemo, kakšno podobo imajo drugi o nas, je to lahko odlično sredstvo samospoznanja, ki vodi v osebno preoblikovanje. Tako lahko npr. razumemo, da so drugi veseli, ko smo mi veseli, ali pa nas pomiri, ko z empatijo razumemo, da so drugi sočutni ob naši žalosti. Ob tem se odpirata polje vzajemnega deljenja sveta in možnost, da lahko tudi sebe doživljamo kot resničnost, ki se nahaja v tem svetu. Steinova namreč poudarja, da nase ali na lastne izkušnje ne moremo gledati kot na del sveta, dokler nismo doživeli, da so nas drugi razumeli in s tem potrdili, da sploh obstajamo. (Simonič 2010, 108-109)

\subsection{Empatija in odnos z Bogom}

Čeprav so drugi in stik z drugimi pomembni za razumevanje nas samih, pa je potrebna tudi milost, ki prihaja od Boga. Empatija in empatične izkušnje so sicer temelj samospoznanja, vendar pa je lahko to samospoznanje povezano z mnogimi napakami, ki nam ostanejo skrite, dokler Bog s pristnim notranjim dotikom in klicem $\mathrm{v}$ notranjosti ne sname teh vezi, ki onemogočajo človeku, da bi v polnosti razumel globine svoje biti. Popolno samospoznanje in spoznanje drugih tako brez Boga in njegove milosti ni mogoče. Je pa empatija tudi način, kako lahko verniki spoznajo Boga, in obenem, kako Bog razume človeška življenja. Empatija zagotovo ne daje popolnih odgovorov o vseh skrivnostih, ki so v nas in v drugih, je pa mogoče z njo začutiti presežno v človeku. Človeka ni mogoče popolnoma določiti, v svoji kompleksnosti ostaja vedno odprto vprašanje. Nobeno človekovo prizadevanje ne more do absolutne popolnosti, pač pa je njegovo bistvo ravno $v$ tem, da povsod, tudi v svojem prizadevanju 
za spoznanje samega sebe, ostaja nedorečen, omejen in odprt za nove raziskave, nova spoznanja. Empatija je pripomoček na poti odkrivanja človeka in njegovih razsežnosti. (Simonič 2010, 109-110)

\section{Dialoškost človeka in pomen empatije}

Ljudje smo po svoji naravi zaznamovani za življenje z drugim, torej za dialog. Človek je kot oseba del skupnosti in njegova osebna zgodba se prepleta z zgodbami družinskih članov, naroda in celotnega človeštva. (Žalec 2005, 2-8) Martin Buber v stiku človeka $z$ drugim človekom vidi ključno antropološko zakonitost. Po njegovem mnenju človeka kot posameznika ne moremo razumeti samo z vidika njegovega notranjega dogajanja, temveč ga moramo obravnavati glede na njegove odnose s stvarmi in bitji. "Človek more postati cel/popoln le v moči odnosa do nekega drugega sebstva." $(1999,77)$ Temeljno bistvo človekovega obstoja je dialoškost, biti človek s človekom. V tej sferi pa dva komunicirata in ustvarjata področje, ki je več kot le skupek posameznih področij dveh oseb. To je novo področje, ki ga je Buber imenoval področje vzajemnosti (nem. das Zwischen). Iz tega področja lahko vznikne resnični tretji (Žalec 2002, 123-124). To je prostor, ki ga lahko imenujemo kraljestvo vzajemnosti ali dialoga in je onkraj osebnosti vsakega posameznika. V njem se srečujeva jaz in ti. (Theunissen 1977, 243-277)

V tej neizogibni realnosti je seveda pomembno, kakšni sta kakovost in globina te vzajemnosti oz. dialoga. Drugemu (in drugi nam) se v večji polnosti približamo samo takrat, kadar ga razumemo v celovitosti njegovega doživljanja. V tem kontekstu empatija izstopa kot zelo pomembna medosebna kompetenca, ki omogoča prepoznati drugega kot osebo, nato pa se tudi potopiti v njegov okvir doživljanja in tako razširiti polje razumevanja neke situacije. Empatija tako omogoča presegati egocentrični pogled na svet in zavzeti sociocentrični pogled na svet, kjer lahko celoviteje razumemo svojo pozicijo in pozicijo drugega (O'Hara 1997, 303-309). Na tej osnovi pa je mogoče tudi dejavneje delovati v svetu, saj se poglobi kritično razmišljanje, sproži se spreminjanje družbene zavesti in aktivira upoštevanje celovitejšega konteksta, to pa vodi v odločitve in dejanja, s katerimi lahko velikokrat preprečimo tudi številne družbene katastrofe in tragedije (Boler 1997, 254-255). Obenem pa tak način vodi tudi v družbo, ki je prosocialno 
orientirana, saj empatija omogoča prepoznavanje stiske drugih in odzivanje nanjo. Tako se ustvarja civilizacija ljubezni, ki temelji na evangeljskih vrednotah in sega na vsa polja človeškega obstoja - socialno, kulturno, ekonomsko, politično. (Osewska in Simonič 2019, 24) Empatija je velikokrat povezana s skrbjo za druge in z občutkom za pravičnost, kot taka pa pomembno vpliva na moralne sodbe posameznika ter na to, kako in kakšne odločitve bo v življenju sprejemal. (Zahn-Waxler 2002, 224)

Zelo pomemben vidik, o katerem govori Edith Stein (1989, 88-89), je, da nam empatija omogoča prepoznati tudi to, kdaj so naša dejanja do drugih slaba. To spoznanje nam omogoča, da stanje, ki smo ga s svojimi dejanji prizadejali drugim, lahko tudi popravimo, kar je zelo pomembno tudi v soočanju s konflikti in procesih medosebne sprave. Empatija je tako ključna komponenta v procesih, ki vodijo k razrešitvi globokih družbenih in medosebnih zapletov in sporov, saj pripomore k učinkovitejšemu razreševanju začaranega kroga medsebojnega obtoževanja in iskanja krivca ter hitreje privede ne le do prekinitve teh vzorcev, pač pa tudi do očiščenja in sprave, ko omogoča resnično razumevanje zapletenosti in globine neke situacije ter obnašanja določenega posameznika ali skupine ljudi v povsem specifičnih zgodovinskih okoliščinah. (Simonič 2012, 271-271) S tem se odpira možnost za pravi in konstruktiven dialog, ki lahko privede do sprave tako v širših družbenih procesih kakor tudi v kontekstu intimnejših medosebnih odnosov (npr. partnerskih, družinskih, prijateljskih).

Empatija je sposobnost, ki omogoča spoznati drugo osebo, ne da bi pri tem posegali $\mathrm{v}$ njeno svobodo in neodvisnost in ne da bi pri tem kršili etična načela. Tako sta ohranjeni in priznani svetost in integriteta drugega človeka kot osebe, s tem pa se empatija odpira tudi v polje presežnega. Drugega dojemamo kot kompleksno bitje, kakršno smo mi sami, saj je drugi prav tako čuteče živo telo, ki pripada jazu, kakor moje čuteče živo telo pripada mojemu jazu. Druge je tako mogoče prepoznati kot osebe. (Stein 1989, 56-63) Čeprav je empatija po svoji naravi lahko zelo nevtralna v smislu, da omogoča zgolj pridobiti neko informacijo o doživljanju drugega, pa je v nadaljevanju vedno tista, ki vodi v globlje in rahločutne interakcije z drugimi, v dialog, kjer smo resnično lahko »človek s človekom«. Empatija je tako več kot samo informacija o odnosih: je izraz tega, da smo v vzajemnih odnosih, to pa je ena izmed psihično najpomembnejših človeških izkušenj. 


\section{Sklep}

Empatija je torej kompetenca, ki je pomembna za vse nas, saj nas ne zapira v lastni svet, temveč spodbuja razvoj iskrenosti, razumevanja, odprtosti do soljudi, tudi do tistih, ki so zaradi svojih sociokulturnih, religioznih, jezikovnih, etničnih ali drugih značilnosti drugačni od nas. Drugačnost oz. nepoznavanje drugačnosti je lahko tudi vzrok za strah in občutek ogroženosti, kar lahko vodi v nestrpnost in sovraštvo do različnosti. Empatija pomaga voditi spoštljiv dialog z vsemi, ko pomaga razumeti kompleksnost situacije drugih in priznava drugemu, ki je prav tako oseba kot mi sami, pravico do njegove individualnosti. (Calloway-Thomas 2010, 3-6) Edith Stein s svojim pojmovanjem empatije pa tudi s svojim življenjem, delom in darovanjem, v jedru katerih je bilo empatično razumevanje drugega, uči, da je empatija ključna kompetenca, ki nas ne zapira v lastni svet, temveč spodbuja razvoj odprtosti in spoštovanja do soljudi. Vodi stran od prehitrega obsojanja, kritiziranja in pametovanja, saj od drugih ne moremo enostavno pričakovati, da so kakor mi, da čustvujejo in razmišljajo tako kot mi, kar bi lahko vodilo do posplošitev, te pa bi porodile samo nestrpnost in razočaranje. Empatija je tako v jedru vsakega kompetentnega in pristnega dialoga, ki temelji na enakovrednem odnosu med različnimi ljudmi.

\section{Reference}

Baron-Cohen, Simon. 2003. The essential difference: The truth about male and female brain. New York: Basic Books.

Boler, Megan. 1997. The risks of empathy: Interrogating multiculturalism's gaze. Cultural Studies 11/2: 253-273. https://doi.org/10.1080/09502389700490141

Borden, Sarah. 2003. Edith Stein. London: Continuum.

Buber, Martin. 1999. Problem človeka. Ljubljana: Društvo Apokalipsa.

Calloway Thomas, Carolyn. 2010. Empathy in the global world: An intercultural perspective. Thousand Oaks: Sage.

Duan, Changming, in Clara E. Hill. 1996. The current state of empathy research. Journal of Counseling Psychology 43/3: 261-274.

https://doi.org/10.1037/0022-0167.43.3.261
Gallese, Vittorio. 2003. The roots of empathy: The shared manifold hypothesis and the neural basis of intersubjectivity. Psychopathology 36/4: 171-180. https://doi.org/10.1159/000072786

Guttman, Herta A. 2000. Empathy in families of women with borderline personality disorder, anorexia nervosa, and a control group. Family Process 39/3: 345-358.

Hribar Sorčan, Valentina. 2008. O empatiji in intersubjektivnosti. Anthropos 1-2: 11-25.

Lachmann, Frank M. 2008. Transforming narcissism: Reflections on empathy, humor, and expectations. New York: The Analytic Press, Taylor \& Francis Group. 
Nilsson, Peter. 2003. Empathy and emotions. Doktorska disertacija. Oddelek za filozofijo, Univerza Umeå.

O'Hara, Maureen. 1997. Relational empathy: Beyond modernist egocentrism to postmodern holistic contextualism. V: Arthur C. Bohart in Leslie S. Greenberg, ur. Empathy reconsidered: New directions in psychotherapy, 295-320. Washington: American Psychological Association. https://doi.org/10.1037/10226-013

Osewska, Elzbieta, in Barbara Simonič. 2019. A civilization of love according to John Paul II. The Person and the Challenges 9/1: 23-32. https://doi.org/10.15633/pch.3359

Tangeny, June Price, in Ronda L. Dearing. 2002. Shame and guilt. New York: Guilford Press.

Rifkin, Jeremy. 2009. The empathic civilization. New York: Jeremy P. Tarcher/ Penguin.

Simonič, Barbara. 2010. Empatija kot temeljni antropološki odnos: Od izročila preko Edith Stein do relacijske teorije. Doktorska disertacija. Teološka fakulteta Univerze v Ljubljani.

--- .2012. The horizons of reconciliation after traumatic experience. V: Janez Juhant in Bojan Žalec, ur. Reconciliation. The way of healing and growth, 267-274. Münster: Lit Verlag.
Stein, Edith. 1989. On the problem of Empathy. Washington: ICS Publications.

Stueber, Karsten R. 2006. Rediscovering empathy. Cambridge: The MIT Press.

Škof, Lenart. 2002. Sočutje med religijo in filozofijo. Ljubljana: Teološka fakulteta.

Theunissen, Michael. 1977. Der Andere: Studien zur Socialontologie der Gegenwart. Berlin: De Gruyter.

Van der Mark, Ingrid Louise. 2001. The development of empathy and compliance in toddlers: The role of parenting, attachment, and temperament. Leiden: samozaložba.

Zahn-Waxler, Carolyn. 2002. The development of empathy, guilt, and internalization of distress. V: Richard J. Davidson, ur. Anxiety, depression, and emotion, 222-265. New York: Oxford University Press.

Žalec, Bojan. 2002. Meanings of identity. Anthropological Notebooks 7/1: 117-135.

- --. 2005. Doseganje dobrega. Ljubljana: Claritas. 